\title{
EVALUATION OF LINEAR ACCELERATOR UTILIZATION FOR CA MAMMAE RADIOTHERAPY AT A PRIVATE HOSPITAL
}

\author{
Evaluasi Penggunaan Linear Accelerator untuk Radioterapi Ca Mammae di \\ Rumah Sakit Swasta
}

\author{
${ }^{*}$ Feliana Mirnawati ${ }^{1}$, Sutopo Patria Jati², Johanes Sugiarto ${ }^{3}$ \\ ${ }_{1,2,3}$ Faculty of Public Health, Diponegoro University, Indonesia \\ *Correspondence: feli_dr@yahoo.com
}

\begin{abstract}
Background: Radiotherapy is an important cancer therapy in Indonesia. For hospitals which have provided radiotherapy tools for more than five years, they need to evaluate its utilization and influence on patients' condition.

Aim: This study aims to analyze the use of Linac for radiating breast cancers in one of a type-C private hospital in Central Java by using Health Technology Assessment.

Method: This study is an observational and descriptive study with an in-depth interview. There were 72 medical record documents examined. Furthermore, the researchers calculated the profits from the financial feasibility of tool investment gained by the hospital. This study involved six Key Informants and four triangulation informants.

Results: This study shows that in terms of effectivity aspect, one Linac can prolong patient waiting time about 2-4 weeks. Such a long waiting time may cause disease progression to increase. Meanwhile, seen from the technical characteristics, the tool is not well-maintained by the internal and external parties. It causes the tool's performance worse. In terms of the economic aspect, the tool has lasted for 7.5 years, but it technically has been utilized for ten years. Therefore, the hospital needs to supply more radiation tools.

Conclusion: The Linac utilization in a year increased, and the ca mammae patient visits were high. In addition to those aspects, the profits gained from the health services were high as well. The hospital should add radiation tools to improve the radiation capacity and decrease patient waiting time.
\end{abstract}

Keywords: linac, economic evaluation, Ca Mammae.

\section{ABSTRAK}

Latar Belakang: Radioterapi adalah terapi kanker yang penting di Indonesia. Bagi RS yang sudah memiliki alat radiasi terutama yang sudah lebih dari 5 tahun perlu dilakukan evaluasi untuk mengetahui bagaimana utilisasi alat dan pengaruh penggunaan alat tersebut terhadap pasien.

Tujuan: Penelitian ini bertujuan untuk melakukan analisis terhadap pemakaian alat Linac untuk radiasi kanker payudaradi salah satu $R S$ swasta tipe $C$ di Jawa Tengah dengan metode Health Technology Assessment.

Metode: Jenis penelitian deskriptif dengan observasi dilanjutkan wawancara mendalam, telaah 72 dokumen rekam medis dan analisa menghitung keuntungannya berdasarkan investasi alat. Penelitian ini melibatkan 6 informan utama dan 4 informan triangulasi.

Hasil: Penelitian menunjukkan dari aspek efektifitas dengan satu buah alat Linac tingkat antrian pasien 2 - 4 minggu sehingga dapat meningkatkan progresifitas penyakit. Dari aspek karakteristik teknis pemeliharaan alat tidak rutin dari pihak internal dan pihak eksternal, menyebabkan umur teknis alat semakin cepat dan aspek ekonomi umur alat saat ini 7,5 tahun, dimana umur teknisnya yaitu 10 tahun sehingga dibutuhkan penambahan alat radiasi.

Kesimpulan: Peningkatan pemakaian alat Linac per tahun dan meningkatnya jumlah pasien ca mammae serta berdasarkan hasil perhitungan keuntungan RS dari investasi alat tersebut, perlu ada penambahan lagi alat radiasi untuk menurunkan tingkat antrian pasien radiasi.

Kata kunci: linac, evaluasi ekonomi, Ca mammae.

Received: 31 May 2019

\section{INTRODUCTION}

Radiotherapy is one of the alternatives for people with cancer since cancer types increase in number (Rodin et al., 2017). Radiotherapy is a kind
Accepted: 19 August 2019

Published: 23 October 2019

of medication for tumors or severe cancers by using electromagnetic radiation (X-Ray and Gamma) and particle radiation (electron, proton, and neutron) (Khabaz, 2018; Khaledi et al., 2018). Some radiotherapy tools are developed, such as Linear 
Accelerator (Linac) (Ono et al., 2018). Linac is a tool that uses a high frequency of electromagnetic waves to accelerate electrons with high energy through a linear tube (Zhu et al., 2018). Linac can be used for radiation of all cancer cases. Breast cancer is the most common disease found at one of the private hospitals of Central Java with more than $50 \%$ visits from 2012 to 2017 . In 2018, 58\% of breast cancer cases occurred at the hospital.

Private hospitals are competing to promote their excellent healthcare, especially the procurement of advanced medical instruments. One of them is Linac, a radiotherapy tool to kill cancer cells (Fantidis, 2018). Linac with significant advancement and highly cost is provided in the type-C hospital to enhance community demands on healthcare for purpose and time. Linac may have a defect because of operational factors and high intensity of use (Gabriela Soto-Bernal et al., 2018).

Type-C hospitals have never evaluated the use of Linac due to the number of visits at the radiotherapy unit and $\mathrm{Ca}$ mammae cases which are the most common cancers in Indonesia especially at hospitals of Central Java (Harahap, Khambri, and Rustam, 2018). From 2012 to 2018, the average use of Linac tools was 43 radiations per day. Whereas, in 2018, the average use of Linac tools per day was 56 times. There was $7 \%$ increase in visits per year. The increase of Linac operation per day can affect its effectiveness and efficacy. To ensure the healthcare quality for $\mathrm{Ca}$ mammae patients who need radiation, an evaluation on the utilization of Linac at the type-C hospital during National Health Insurance era is necessary by using Health Technology Assessment (HTA) (Salim and Danil Julian, 2018). According to Presidential Regulation of Republic of Indonesia Number 12 of 2013 about National Health Insurance, to ensure the quality control and financial control, the Ministry is responsible for health technology assessment. The utilization of technology for health insurance must comply with the medical needs based on the results of Health Technology Assessment / HTA.

Based on the data from the hospital, there was a significant increase of Linac utilization at $99.9 \%$ for patients with health insurance (Yunasfi et al., 2003). The Linac has been utilized for 7.5 years and 60 hours in a week to radiate 55-65 patients in a day. Because of the high number of Ca mammae cancers with 1.79 probability per 1000 people, the analysis of Linac utilization can be references to procure and invest future medical tools.

Health Technology Assessment (HTA) is the most proper way of evaluating the utilization of medical tools at hospitals (Olberg et al., 2017). HTA evaluates various aspects in the utilization of health technology, such as operational characteristics, safety, efficacy, effectivity, economic and social aspects, ethics, legality, politics, and religion (Kelley et al., 2018). Hospitals can use the evaluation of HTA for procuring and investing Linac in the future (Marsh et al., 2016).

This study aims to evaluate the utilization of Linac for Ca mammae cases by using the Health Technology Assessment (HTA) (Kelley et al., 2018).
The HTA analyzes data in terms of efficacy aspect or technical characteristics, effectiveness aspect, economic aspect, safety including radiotherapy unit and hospital managerial unit, perspectives of radiation oncologists and $\mathrm{Ca}$ mammae patients collected through observation, interviews, calculation of profits from the financial feasibility of the tool investment and medical record analysis towards the use of Linac (Goodman, 2014). The scope of this study is to conduct research based on the process and output of Linac utilization at the type-C hospital during National Health Insurance.

\section{METHOD}

This study uses a qualitative method and collects data through in-depth interviews, secondary observation, document review, and benefit calculation of tool investment. Observation was conducted in May 2019. There were 72 medical records in the period of 2015 to 2019 from patients who were treated by using Linac. Also, the researchers in this study calculated the profits from the financial feasibility of the tool investment obtained by the hospital, conducted an in-depth interview, unstructured interview to the selected informants.

The key informants include a radiation oncologist as a functional medical staff radiotherapy, a radiographer as a permanent employee who has worked for more than two years, a medical technician as a permanent employee who has worked for more than two years and maintained the Linac tool. The other three key informants are breast cancer patients who completed the radiation therapy stages a year ago. The study also invites triangulation informants, such as the Head of radiotherapy installation, the Coordinator of radiotherapy installation as a permanent medical physicist for more than five years, and the Hospital Director who is responsible for hospital services and finance.

The study was done in the Radiotherapy Unit at one of type-C private hospitals of Central Java. This hospital is an excellent hospital for comprehensive cancer care, which is connected to anatomy pathology laboratory and chemotherapy. It also becomes referred to the hospital for radiation treatment in Indonesia. The Radiotherapy Unit has utilized the radiation tool since 2012 with 12-hour operation per 5 working days and about 55-65 patients per day. The hospital had also partnered with the Social Security Agency for Health or BPJS Kesehatan since the National Health Insurance started in 2014. The data in this study were collected from data of patient visits in the period of 2012 - 2018. There were 170 general patients and 959 patients with health insurance. Comparing the percentage of patient visits, there were $18 \%$ of general patient visits and $82 \%$ of patients with health insurance from 2012 to 2018 . Whereas, since 2017 , the number of general patients has been $0.1 \%$ of total patients. From 2012 to 2018 , the Linac was utilized for 72,151 times, so the average use per year was 10,308 times. It was found that the 


\section{[DJAKI \\ IURNAL ADMINISTRAS
KESHHATAN INDONESIA \\ INDONESLAN IOURNAL OO}

Linac was used for 43 radiations in a day (in 5 working days with or without day-off). Meanwhile, in 2018, the frequency of Linac utilization was 13,370 times with average use of 56 radiations per day.

This study analyzed the data by utilizing the Health Technology Assessment (HTA). The data were assessed in terms of effectiveness aspect by paying attention to the level of illness recovery, the results of therapy using Linac, and the number of patient visits perceived from the number of medical records (Sastroasmoro, S.and Nadjib, M., 2018). The second aspect was the clinical aspect which undergoes analysis of Linac utilization and maintenance through observation and in-depth interview with health technicians. Third, the safety aspect was measured through direct observation, reports of medical records, or reports of side effects on clinical tests (Goodman, 2014). The fourth aspect was the economy which involves macroeconomy aspect by comparing hospital and INACBGs charges and microeconomy by analyzing the Cash Flow (Putu et al., 2019), Net Present Value (NPV), Internal Rate of Return (IRR) (Gustirani, 2017) and Payback Periode (PP) (Szczerba and Huesch, 2014) to discover the profits from the financial feasibility of the tool investment obtained by the hospital during National Health Insurance era.

\section{RESULTS AND DISCUSSION}

The study shows the analysis of Linac utilization for 7.5 years since 2012 at a type-C private hospital of Central Java with HTA method. There are four aspects evaluated which are effectiveness, technical characteristics, safety, and economy (Olberg et al., 2017).

\section{Effectiveness Aspect}

Based on 72 medical records of radiated patients and observation of service flow in the Radiotherapy Unit, the initial stage before the radiation is CT simulator which allows contouring to occur in several minutes, but the dose planning needs four days for one patient. Then, a radiation oncologist needs to check it within three days. After that, the radiation treatment can be scheduled for the patient. The next stage is the first radiation, which is observed from the CT simulator within a week and a month at its finest. The average frequency of radiation is two weeks, and the longest is one month due to the long waiting time and instrument defect. Whether Ca mammae patients are radiated in 10 minutes or 30 minutes is based on the different cancer stages and locations.

Table 1. Medical Record Documents of Cancer Patients.

\begin{tabular}{ccc}
\hline $\begin{array}{c}\text { Cancer } \\
\text { Stage }\end{array}$ & $\begin{array}{c}\text { Number of } \\
\text { Patients }\end{array}$ & Age Range \\
\hline 1 & 4 & $35-60$ years \\
\hline 2 & 19 & $35-60$ years \\
\hline 3 & 38 & $35-60$ years \\
\hline
\end{tabular}

Published by Universitas Airlangga

Doi:10.20473/jaki.v7i2.2019.132-138

Table 1 shows the radiation to all $\mathrm{Ca}$ mammae stages (stage 1 to stage 4). The initial dose for each stage is different. Even though some patients have the same cancer stage, they receive different radiation dose according to the treatment from the radiation oncologists. Based on the document analysis, the first phase delivers twentyfive fractions and five fractions. The level of healing due to the use of Linac is measured from the level of recurrence. According to 72 medical records which patients started radiation treatment in 2015 and completed it in 2019, only one patient faced recurrence. It means the utilization of Linac results in one percent of recurrence. Based on the monitoring of physical check-up and regular blood laboratory check-up per 5 fractions radiated to patients, two patients $(3 \%)$ get less radiation than the other five patients $(7 \%)$. It was found that 12 patients $(17 \%)$, two patients $(3 \%)$, nine patients $(13 \%)$ and one patient $(1 \%)$ suffered from anemia, thrombocytopenia, leukopenia, and leukocytosis respectively.

The in-depth interview results show that the CT simulator of Linac needs time to draw cancer organ and plan the dose to minimize the radiation effect around the organ. As well, it optimizes the dose for target organ in which radiation dose is different from one patient to another according to the cancer stage. The CT simulator takes two weeks to complete these processes, so the radiation is scheduled at least two weeks after chemotherapy or surgery. Thus, the length of the radiation process and long radiation schedule from 2 weeks to one month may influence the progressivity of disease. The radiation dose is evaluated every time five fractions are given, and physical treatment by a doctor and regular blood laboratory tests are accomplished. The dose will be re-calculated if patients do not continue radiation treatment within one week. As a result, the radiation schedule is late, and the waiting list of patients increases. Eventually, it worsens the patient's condition and the progressivity of disease. The cancer surgery can decrease the level of cancer recurrence $20-60 \%$ of the number of patients. Whereas, the use of Linac can reduce the recurrence of about $10-20 \%$ of the number of patients. In 2019, $1 \%$ of recurrence occurs out of 72 patients as samples and is still reasonable.

"The success of radiation is dependent on the stages and risk factors that patients have, patients' age, the successful surgery, hormones, etc. For example, for patients with cancer stage 1 , the survival level within five years can be about 65\%-90\%. Whereas, patients with cancer stage 4 have $15 \%$ of survival level within five years. The level of healing can be seen from the frequency of recurrence and survival. For curative treatment, if patients do not get radiated, the recurrence can be over $20 \%$. 
However, if they get radiated, the recurrence will be lower than $15 \%$. For palliative treatment, the radiation may reduce the pain that patients feel". (Key Informant 1)

"The purpose of radiation is to reduce the recurrence risks around the location of cancer in the body organ. Radiation can decline the frequency of recurrence significantly in any stages, which will show different results according to the patient's age and general condition. Surgery can decrease the frequency of recurrence about up to $20-60 \%$ out of total cancer patients. Meanwhile, the utilization of Linac can reduce the recurrence risks about $10-20 \%$ out of total cancer patients." (Triangulation Informant 1)

Table 2 shows the utilization of Linac-based on the patient visits at the Radiotherapy Unit, where a patient undergoes at least 25 radiation fractions. From 2012 to 2018, the average utilization of Linac was 72,151 radiations, so the average use per year was 10,308 radiations. It means that the average radiations of Linac operations per day were 43 within five working days (not including holiday). In 2018, the frequency of Linac utilization was 13.370 radiations with the average operation per day of 56 radiations.

\section{Technical Characteristic Aspect}

Based on the analysis of 72 medical records, observation on the flow of service at the radiotherapy unit, it was found that three patients got delayed radiation treatment because the Linac could not work properly for a week in January 2016 and November 2018. The in-depth interview results show the Linac has been operated at this type-C private hospital of Central Java for 7.5 years with ten year-operational periods. The Linac is used for 12 hours per day out of 5 working days for about 55 60 patients in total. Ideally, there are about 40-50 patients per day treated with 3D conformal radiation. The hospital and on-call service check the Linac every three months. They need to repair the tool parts, which are a bit expensive and takes expensive maintenance (Song et al., 2010).

Table 2. The Utilization of Linac From 2012 to 2018.

\begin{tabular}{cc}
\hline Year & $\begin{array}{c}\text { The Frequency of Linac } \\
\text { Radiations }\end{array}$ \\
\hline 2012 & 4423 \\
\hline 2013 & 5391 \\
\hline 2014 & 9451 \\
\hline 2015 & 12611 \\
\hline 2016 & 14031 \\
\hline 2017 & 12874 \\
\hline 2018 & 13370 \\
\hline Total & 72151 \\
\hline
\end{tabular}

Recently, the waiting list for radiation takes about two weeks until one month because of the abundance of patients. Each radiotherapy takes at least 10 minutes, so the radiotherapy unit needs to limit the quota of patients based on the operating hours. Meanwhile, many other hospitals usually provide cobalt as a radiation tool. Based on the Accelerator Technology and Material Processing Center (Iswinning Diah and Anggraita, 2014), the radiation techniques with Linac and Cobalt are different, and the radiation effect is more optimal if the Linac is used. The side effect that resulted from the use of Linac is also minimal compared to the use of cobalt. Moreover, cobalt waste is more dangerous than Linac (Guritna et al., 2018). This argument is more evidenced by what Key Informant 1 and Triangulation Informant 4 said.

"In 2030, cancer cases will increase three times in developing countries. It is expected that the tools are more provided. Considering the high maintenance cost as much as 2 trillion, the hospital should decide whether or not to buy a new appliance or maintain the old one. If we buy a new tool, we must add the capacity of radiation and several human resources. Besides, Siemens Primus will end of support in 2022, meaning that there will be no spare part officially commerced. By adding the number of tools, it will be beneficial to develop a center for cancer and cooperate with other surrounding hospitals." (Key Informant 1)

"Based on the average visit per day, which needs 60 radiations, the hospital management unit says that the tools provided are inadequate by considering the tools' capacity and operational period. We plan to add more new tools in two to three years later. If the existing Linac is maintained a bit longer up to 5 years later, maybe there will be two tools used at the same time in the third year". (Triangulation Informant 4)

According to the Accelerator Technology and Material Processing Center, the use of Cobalt-60 for radiotherapy is relatively cheaper and simpler, but has various disadvantages in terms of radiation techniques and side effects after radiation (Iswinning Diah and Anggraita, 2014). Thus, many developed countries do not use it anymore instead choose a linear accelerator. Some advantages of using a linear accelerator with high-energy $X$-rays or HEX-rays or electrons are to give a greater dose and choose higher energy for head and neck cancers. Moreover, the linear electron accelerator can be switched on and off as necessary, and its dose can be controlled. Mainly, it does not produce radioactive wastes.

The National Nuclear Energy Agency for Technology Accelerator and Process Center 


\section{[DJAKI \\ IURNAL ADMINISTRAS
KESHHATAN INDONESIA \\ INDONESLAN IOURNAL OA}

mentions cobalt as the other radiation equipment owned by many hospitals. The cobalt tool uses 2D technique while Linac uses 3D technique which can calculate doses accurately. Thus, using 3D technique can optimize the expected results, but minimize the side effects without waste, so it is safe for employees, patients, patient families and other visitors (Yunasfi et al., 2003).

\section{Safety Aspect}

Based on the analysis of 72 medical records and observation on the service flow at the radiotherapy unit, the side effect caused by the radiation is different from one patient to another. There are 25 patients who got hyperpigmentation $(35 \%), 7$ patients who got lesion $(10 \%), 6$ patients who felt itchy $(8 \%), 2$ patients who are wounded $(3 \%), 2$ patients who felt sore throat $(3 \%), 1$ patient who got mouth ulcer (1\%).

Based on the in-depth interview, in terms of the safety level of the Linac, the side effects of the Linac utilization include hyperpigmentation, a lesion in the radiated skin, skin infection, esophagitis which only can be cured by using oral or topical medication. The safety level in terms of buildings and infrastructure as well as facilities have complied with the standard, such as a bunker and a waiting room. The health personnel at the radiotherapy wear TLD (Thermoluminescent Dosimeter) badge to measure the exposure of radiation. Every three months, the TLD is sent to the National Nuclear Energy Agency for tool check. It was found that the radiation exposure is still normal. The National Nuclear Energy Agency also annually checks the waiting room and the bunker which have normal radiation exposure (Lima Flores et al., 2017). These results are supported by the arguments of Key Informant 2 and Triangulation Informant 2.

"The radiologists must wear TLD badge which is sent to the National Nuclear Energy Agency every three months to measure the radiation exposed. Meanwhile, for the safety of patients and visitors, the waiting room and bunker are safe. The National Nuclear Energy Agency annually check all places at the radiotherapy unit. Until now, it is still safe, so does not need any particular rooms for visitors since patients stay in the bunker according to the standard of National Nuclear Energy Agency". (Key Informant 2)

"TLD (Thermoluminescent Dosimeter) is used to measure the radiation exposure and sent to the National Nuclear Energy Agency for tool check every three months. The level of radiation exposure is still normal. The Linac in the bunker is properly placed to prevent radiation outside. The radiotherapy room is checked every three months to make sure that the
Doi:10.20473/jaki.v7i2.2019.132-138

radiation in the room is below five millisieverts, and the radiation from the $T L D$ is below ten millisieverts by using a survey meter". (Triangulation Informant 2)

\section{Economic Aspect}

Based on the in-depth interview, due to the high cancer prevalence and unavailability of radiation tool in Indonesia, radiotherapy at the type C private hospital in Central Java becomes a national referral. However, many patients at several hospitals are registered in the waiting list because of the tool defect and no back-up tool, so they get referred to other hospitals (Zahrotiah et al., 2015). Using the payment method of the Indonesian CaseBased Group (INA-CBGs) will make the cost of radiation treatment cheaper than the cost charged by the type-C private hospital. However, if the profits from the financial feasibility of the tool investment are analyzed by using Payback Period and Net Present Value, hospitals maybe will get more profits. Thus, this evaluation can be used by the hospital to invest other tools in the future.

The treatment cost charged by the hospital includes the Treatment Planning System (TPS) and CT simulator in the first fraction, doctor consultation charges in the first treatment and final treatment, as well as laboratory check for routine blood tests every five fractions. However, if patients choose the payment method of INA-CBGs, they only will pay the treatment in every fraction, including the charges for TPS, CT simulator, doctor consultation, and laboratory check. If every patient uses the payment from the Social Security Agency for Health, he will receive 30 fractions with the total cost of IDR $23,070,000,-$ or IDR $769,000,-$ per a radiation fraction. Meanwhile, for one patient without such payment method, he will be charged as much as IDR $31,539,140$,- per 30 radiation fractions or IDR $1,052,305,-$ per a radiation fraction. The difference between the costs paid by the patient from the Social Security Agency for Health and the patient with general payment is IDR $8,469,140$,- or IDR 282,305 ,- per each radiation fraction. However, it has not been in conclusion whether this cost difference may result in a financial loss for the hospital. Further research about the financial feasibility of the tool investment should be done.

Based on the revenues, the operational period of the tool is one year up to 10 years. Then, the total cost from 1 to 10 year-operational period is calculated, and the operational profit after and before the Value-Added Tax (VAT) given is calculated to measure the cash flow. Based on the annual cash flow with the interest rate of $12 \%$, the calculation of Net Present Value for the Linac investment is presented in Table 3.

The Present Net Value in Table 3 is obtained from the supporting documents of revenues and expenditure made by the radiotherapy unit. The NPV for the Linac investment is (+) Rp $12,120,474,391,-$, meaning that the hospital can invest the Linac. The Internal Rate of Return (IRR) with the Discount Factor (DF) of $38 \%$ and $36 \%$ is 
$37.10 \%$ which is more than Indonesian bank deposit rates in June 2019 are $8 \%$, meaning that the hospital can invest this tool. Meanwhile, the Payback Period can be obtained in 3 years and eight months. Table 4 shows the results of the Payback Period.

Table 3. The Calculation of Net Present Value for the Linac Investment.

\begin{tabular}{lcr}
\hline Year & $\begin{array}{c}\text { Net Cash } \\
\text { Flow }\end{array}$ & \multicolumn{1}{c}{$\begin{array}{l}\text { Investment } \\
\text { Surplus }\end{array}$} \\
\hline Investment & & $-13,000,000,000$ \\
\hline Year I & $4,856,913,000$ & $-8,143,087,000$ \\
\hline Year II & $4,500,472,594$ & $-3,642,614,406$ \\
\hline Year III & $4,444,030,694$ & $\mathbf{8 0 1 , 4 1 6 , 2 8 8}$ \\
\hline Year IV & $4,706,352,625$ & $5,507,768,912$ \\
\hline Year V & $5,030,957,464$ & $10,538,726,376$ \\
\hline Year VI & $5,416,881,635$ & $15,955,608,011$ \\
\hline Year VII & $5,864,502,663$ & $21,820,110,674$ \\
\hline Year VIII & $7,725,163,971$ & $29,545,274,645$ \\
\hline Year IX & $8,436,928,984$ & $37,982,203,629$ \\
\hline Year X & $9,231,737,949$ & $47,213,941,578$ \\
\hline
\end{tabular}

Table 4. The Calculation of Payback Period from the Tool Investment.

\begin{tabular}{ccr}
\hline \multicolumn{3}{c}{ Net Present value } \\
\hline Description & $\begin{array}{c}\text { Net Cash } \\
\text { Flow }\end{array}$ & Cash Inflow \\
\hline $\begin{array}{c}\text { Interest Rate } \\
\text { of } 12 \%\end{array}$ & $13,000,000,000$ \\
\hline I & $4,856,913,000$ & $4,337,223,309$ \\
\hline II & $4,500,472,594$ & $3,586,876,658$ \\
\hline III & $4,444,030,694$ & $3,164,149,854$ \\
\hline IV & $4,706,352,625$ & $2,993,240,269$ \\
\hline V & $5,030,957,464$ & $2,852,552,882$ \\
\hline VI & $5,416,881,635$ & $2,746,358,989$ \\
\hline VII & $5,864,502,663$ & $2,650,755,204$ \\
\hline VIII & $7,725,163,971$ & $3,120,966,244$ \\
\hline IX & $8,436,928,984$ & $3,045,731,363$ \\
\hline X & $9,231,737,949$ & $2,972,619,619$ \\
\hline $\begin{array}{l}\text { Net Present } \\
\text { Value }\end{array}$ & & $31,470,474,391$ \\
\hline Positive Value & & $12,120,474,391$ \\
\hline
\end{tabular}

The budget surplus of investment is less than the revenues in the third year and eight-month. It can be seen that the hospital can gain PP before the operational period of the Linac, which is ten years ends. The calculation of the Payback Period in Table 4 is obtained from the supporting documents of cash flow at the radiotherapy unit. Most of the visits at these hospitals are dominated by $99 \%$ of patients with national health insurance from the Social Security Agency for Health. Then, the profits gained by the hospital from the tool investment are calculated based on the cash flow, IRR (Internal Rate of Return), NPV (Net Present
Value), and PP (Payback Period). According to the results, the Linac investment is proper to be the hospital's investment with good payback by the end of the tool's operational period. The cancer prevalence gets increasing, and the availability of the radiation tools in Indonesia has not fulfilled the needs. Thus, the hospital opens radiotherapy services for national referrals. Since the waiting list for radiotherapy is long, it can become a business opportunity and profit center for hospitals (Fitriatuzzakiyyah, Sinuraya, and Puspitasari, 2017). Based on the claims using INACBGs, the radiotherapy cost is lower than the cost charged by the hospital. However, it still gives the hospital profits from the tool investment. The hospital can use these findings if they want to invest more tools in the future.

\section{CONCLUSION}

Based on the analysis of the Linac utilization, it can be concluded that the hospital needs to invest more radiation tools because the existing Linac has deficient operational period due to poor maintenance. Thus, it decreases the quality of Linac proven from the frequency of recurrence. Moreover, the number of patients presumably will increase along with the increase of cancer cases in Indonesia so that it may accelerate the number of visits and national referrals with the waiting list within two weeks until one month. If the hospital plans to invest another radiation tool, they need to choose the $3 D$ radiation tool which can measure the right dose for better effect, minimize the side effect, and have no harmful waste for surroundings. Based on the analysis of the economic aspect, the Linac can be invested by type- $C$ private hospitals in the era of National Health Insurance.

Moreover, the hospital should hire more health personnel, especially radiation oncologists, and design an information system at the radiotherapy unit that may give regular therapy schedule to prevent the therapy discontinuity. The regular standard maintenance has periodically been done by the internal health personnel and external service partners. The on-call maintenance service and evaluation on the tool's operational condition of the are vital to support the tool according to its operational period.

\section{CONFLICT OF INTEREST}

The authors state that there is no conflict of interest for this article.

\section{REFERENCE}

Harahap, W. A., Khambri, D. and Rustam, R. (2018) Outcome of young breast cancer women in Indonesia.

10.1016/j.breast.2018.08.069.

Fanditis, J. G. (2018) 'The Use of Electron Linac for High Quality Thermal Neutron Radiography Unit', Nuclear Inst. and Methods in Physics Research, 908, pp. 361-366. doi: 10.1016/j.nima.2018.08.114. 
Fitriatuzzakiyyah, N., Sinuraya, R. K. and Puspitasari, I. M. (2017) 'Terapi Kanker dengan Radiasi: Konsep Dasar Radioterapi dan Perkembangannya di Indonesia', Jurnal Farmasi Klinik Indonesia, 6(4), pp. 311-320. doi: 10.15416/ijcp.2017.6.4.311.

Flores, A. L. et al. (2017) 'Analysis and Characterization of Neutron Scattering of $A$ Linear Accelerator (Linac) on Medical Applications', Journal of Nuclear Physics, Material Sciences, Radiation and Applications, 5(1), pp. 65-78. doi: 10.15415/jnp.2017.51007.

Gabriela Soto-Bernal, T. et al. (2018) 'Neutron Production in the Interaction of 12 and $18 \mathrm{MeV}$ Electrons with a Scattering Foil inside a Simple Linac Head', Applied Radiation and Isotopes, 139, pp. 46-52. doi: 10.1016/j.apradiso.2018.04.024.

Goodman, C. S. (2014) HTA 101 - Introduction to Health Technology Assessment. Bethesda: National Library of Medicine.

Guritna, E. et al. (2017) 'Analisis Elektron Beam Profile Constancy pada Pesawat Linac', Jurnal Fisika FLUX, 14(2), pp. 110-119. doi: 10.20527/flux.v14i2.4134.

Gustirani, I. (2017) 'Analisis Investasi Proyek Pengadaan CT-Scanner terhadap Pendapatan Perusahaan', Jurnal Sistem Informasi, Keuangan, Auditing, dan Perpajakan, 2(1), pp. $1-13$.

Indrayathi, P. A. and Hardy, I. P. D. K. (2017) Manajamen Keuangan dan Logistik dalam Pelayanan Kesehatan. Denpasar: Udaya University

Kelley, L. T. et al. (2018) 'Evaluating Multi-Criteria Decision-Making in Health Technology Assessment', Health Policy and Technology, 7(3), pp. 310-317. doi: 10.1016/j.hlpt.2018.05.002

Khabaz, R. (2018) 'Effect of Each Component of A Linac Therapy Head on Neutron and Photon Spectra', Applied Radiation and Isotopes, 139, pp. 40-45. doi: 10.1016/j.apradiso.2018.04.022.

Khaledi, N. et al. (2018) 'Investigation of Photoneutron Production by Siemens Artiste Linac: A Monte Carlo Study', Radiation Physics and Chemistry, 153, pp. 98-103. doi: 10.1016/j.radphyschem.2018.06.006.

Komite Penilaian Teknologi Kesehatan (2017) Buku Panduan Penilaian Teknologi Kesehatan. Jakarta: Kementerian Kesehatan Republik Indonesia.

Marsh, K. et al. (2016) 'Expanding Health Technology Assessments to Include Effects on the Environment', Value in Health, 19(2), pp. 249-254. doi: 10.1016/j.jval.2015.11.008.

Olberg, B. et al. (2017) 'Scientific Evidence in Health Technology Assessment Reports: An InDepth Analysis of European Assessments on High-Risk Medical Devices', Value in Health, 20(10), pp. 1420-1426. doi: 10.1016/j.jval.2017.05.011.

Ono, T. et al. (2018) 'Geometric and Dosimetric Accuracy of Dynamic Tumor Tracking During
Volumetric-Modulated Arc Therapy Using a Gimbal Mounted Linac', Radiotherapy and Oncology, 129(1), pp. 166-172. doi: 10.1016/j.radonc.2017.10.034.

Rodin, D. et al. (2017) 'Overview Balancing Equity and Advancement: The Role of Health Technology Assessment in Radiotherapy Resource Allocation', Clinical Oncology, 29, pp. 93-98. doi: 10.1016/j.clon.2016.11.001.

Salim, A. and Danil Julian, E. (2018) 'Inadequate Treatment still A Major Problem for Indonesian Young Age Breast Cancer Patients: A Single Institutional Experience', The Breast, 41(1), p. S17. doi: 10.1016/j.breast.2018.08.048.

Song, F. et al. (2010) 'Dissemination and Publication of Research Findings: An Updated Review of Related Biases', Health Technology Assessment, 14(8). doi: 10.3310/hta14080.

Suharni, Iswinning Diah, F. and Anggraita, P. (2010) 'Tinjauan Teknologi Akselerator Linear (Linac) Elekta Precise di RSUP Dr. Sardjito', in Prosiding PPI - PDIPTN 2010 Pustek Akselerator dan Proses Bahan - BATAN. Yogyakarta, pp. 166-175. Available at: http://digilib.batan.go.id/ppin/katalog/file/AP9Suharni_166-175.pdf.

Szczerba, R. J. and Huesch, M. D. (2012) 'Why Technology Matters as Much as Science in Improving Healthcare', BMC Medical Informatics and Decision Making, 12(103), pp. 1-5. doi: 10.1186/1472-6947-12-103.

Yunasfi et al. (2003) 'Penggunaan Akselerator untuk Terapi di Indonesia', in Proseding Seminar Pengembangan Teknologi dan Perekayasaan Instrumentasi Nuklir. Serpong, pp. 97-100. Available https://inis.iaea.org/collection/NCLCollectionSto re/_Public/37/092/37092470.pdf.

Zahrotiah et al. (2015) 'Kanker Pembunuh Papan Atas', Mediakom, February.

Zhu, Y. et al. (2018) 'Design and Simulation of a Linac for High Energy Electron Radiography Research', Nuclear Inst. and Methods in Physics Research, 911, pp. 74-78. doi: 10.1016/j.nima.2018.09.133. 